\title{
The Most Common Mistakes of Teacher Trainees' Former Teachers
}

\author{
Bayram Özer*, İsmail Gelen, Sinem Hızlı Alkan, Gonca Çınar, Volkan Duran \\ Faculty of Education, Ondokuz Mayis University, Turkey
}

Copyright $\bigcirc 2016$ by authors, all rights reserved. Authors agree that this article remains permanently open access under the terms of the Creative Commons Attribution License 4.0 International License

\begin{abstract}
The fundamental parts of the educational processes are teachers and students. The study aims to determine the common mistakes done by teachers in the classrooms. The research was conducted to 278 third year students in the departments of English Language Teaching, Turkish Language Teaching, and Fine Arts Teaching in 2012-2013 academic year. The research was conducted through the descriptive model in the survey research types. "What are the most common mistakes done by teachers in classrooms?" was asked to teacher trainees in questionnaire. The analysis was done by the content analysis among the qualitative research techniques. Findings are classified in the themes of "classroom management and discipline, teaching, communication, personal qualities, ethics, measurement and assessment, and other mistakes". Hence, many problems such as "failure to establish the authority and compensating it through being harsh toward students, being much more authoritarian and disciplined, seeing himself/herself as the authority source" emerged in this perspective. Furthermore, many inadequacies such as not being positive and gentle, negative attitudes, choosing attitudes directing students in a difficult situations, anger, having peaceful mood, threatening students with bad grades, claiming that he/she is the best, reflecting psychological problems in the classroom are determined at the end of the study.
\end{abstract}

Keywords Teacher, Teaching, Teacher Mistakes, Teacher Attitudes

\section{Introduction}

Schools are the institutions in which the main qualifications are orderly transferred in accordance with the main purposes of curriculum. Each school gains its unique character, which is its raison d'etre, through its culture in which it shapes, its structure. Schools have functions in social, individual, political, economic dimensions. Schools have inner constituents as students, curriculum, teachers, administrators, other staff, buildings, tools and equipment and outer constituents such as other institutions in Ministry of Education, parents, civil society organizations, labour market and other organizations. All the internal and external constituents work in a harmony for main purpose of schools [1]. Teachers can be regarded as main agents in the development of society in cultural, economic and other areas in some sense. In order to fulfil the requirements of this role efficiently, teachers should improve themselves in the area of content knowledge of their expertise, pedagogical knowledge and contextual knowledge which they use in classroom environment [2].

\section{Teacher Qualification}

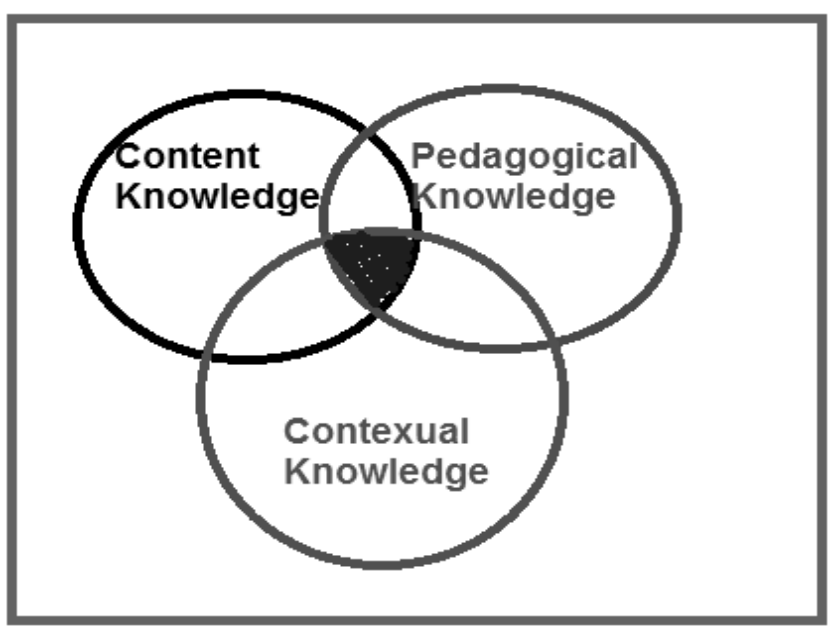

Figure 1. Teacher qualification in terms of three kinds of knowledge.

In this respect, it is important for teachers to hold responsibility of educating the future generations who are potential human sources for countries, to sustain the effective teaching conditions which are compatible with the requirements of current technological developments. In this sense, teachers should have the content knowledge reflecting their expertise, pedagogical knowledge for the transfer of content information in terms of educational principles regarding communicational and teaching skills, classroom management, giving feedback, and contextual knowledge for transferring content information in terms of the needs of 
classrooms, schools and individuals in a flexible manner [4].

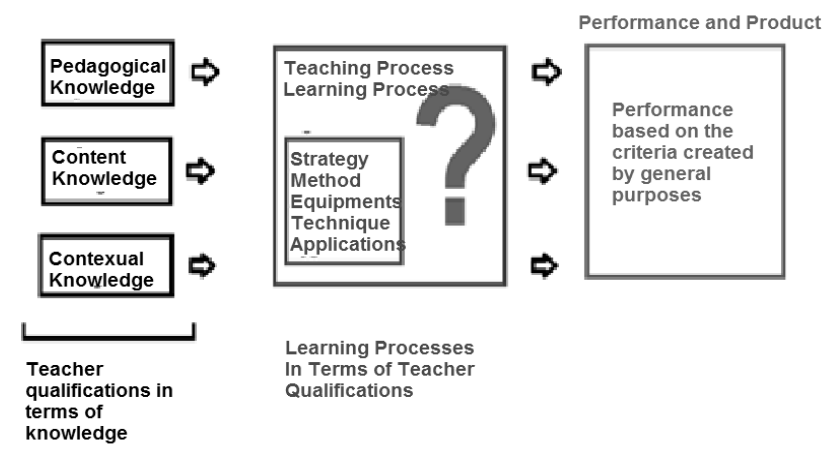

Figure 2. Teachers' performances in educational process can be evaluated in terms of the variables of system approach as input, process and output ( It is modified from CIPP model).

In terms of system approach, educational processes can be evaluated as a whole in which the main constituents of the system as inputs, processes and outputs interact each other dynamically so as to reach the designed purpose of the system [3]. However, if the educational process can be regarded as a black box in which the functioning of the processes is vague, it can be said that the concrete and observable dimensions of teaching emerged in the classroom management and educational processes in classroom conditions. For instance, the praxis in the classroom conditions reveals whether teachers prepare teaching materials or they develop their communication skills. In this regard, classroom management skills which partially include communication skills, time management, representational skills of their pedagogical, contextual, content knowledge can be regarded as one of the concrete criteria to assess the performances of teachers and be efficient in creating feedback for the maintenance of educational outcomes. For example, Emmer and Hickman [5], find out that the qualifications in classroom management and discipline techniques are different from the other areas. This finding can be interpreted as the relationship between classroom management and pedagogical content knowledge.

Classroom culture, rules, teaching methods, ethical rules, hidden curriculum, psychological and sociological classroom characteristics of classroom are done by other concrete constituents of the classroom [1]. Nevertheless, teacher is the person who actively uses those constituents. Schools and classrooms are the first places where qualified individuals are trained. Therefore, it is important to create classroom conditions which are efficient and compatible with the educational purposes. Effective teacher is the one that has the sense of comprehension about the positive and negative factors [6]. The knowledge and awareness of the rules that students should obey, the variables of classroom management, the expectations and needs of students effect the classroom management [7]. All these factors determine the classroom management are interdependent to each other and affect each other mutually.

The aim of the classroom management is to create best learning environment. In order to create such an environment, the entire negative factors should be minimized. In this sense, classroom management includes the arrangement of classroom environment and routines, arranging new strategies towards desired and undesired behaviours, using appropriate reinforcements, the application of new and efficient activities for teaching and learning processes [8]. In this sense, it can be argued that not only desired behaviours but also undesired attitudes may affect classroom management along with the main qualifications of teachers. Especially as for the inexperienced teachers, it is not always possible to lower the undesired behaviours at minimum level [9]. It was found that the teachers who have less abilities in classroom management are tend to criticize students more than the experienced ones [10]. Additionally, teachers not only make mistakes in undesired student behaviours but also they pedagogically make mistakes which are incompatible with curriculum. For example, although the curriculum based on constructive approach, teachers tend to evaluate the student mistakes in the perspective of classical and behaviourist approaches [11]. In this sense determination of the mistakes done by teachers especially in classroom management may imply their needs in pedagogical content knowledge and the required feedback and even more providing in-service training courses with them. Thus, this study partially tries to provide required theoretical background and data for the literature gap.

\subsection{Problem Statement}

Teacher is the required subject of an effective and active education. Effective teacher is also an efficient classroom administrator. "The effective teaching cannot be achieved in a classroom conditions in which mismanagement is dominantly used" [12]. Unless the reasons of mismanagement in classrooms are not well examined, this process continues in the subsequent courses. This results in endless unsolvable questions in education as well. The arrangement of classroom conditions and establishment of classroom discipline is also another factor that can be taken into account. The unawareness of classroom conditions, which have complex dynamics, can also result in the problems in creating effective ways for education.

Teachers' self-perception of their leadership and the way in which they incorporate it in their lifestyles is also another critical subject. Because the leadership that teacher show can affect both schools, teachers and students [13]. Hence, the self-perception of leadership of teachers can change the classroom conditions and atmosphere. The most behaviours of the teachers are directly or indirectly related with behaviours of students in classrooms. For instance, the comparative study done by [14] Örücü (2012) shows that the methods, application and even descriptive statements of the teachers change in accordance with the quality of students for each classroom. According to study done by Akar, Tantekin Erden, Tor and Şahin [15], the behaviours of teachers vary in terms of physical conditions, motivation, the first day experience, rules, general mundane classroom applications, the undesired behaviours and the cooperation 
among school, teacher and parents.

One of the main results of classroom management can be regarded as the leadership. Teachers can help students to make their own decisions freely, and work together collaboratively, give them responsibility, gain their trust, enable them to show behaviours that can control their own behaviours through their characteristics of leadership [16].

Another problem faced in classroom management is not giving responsibility to students because teachers sometimes may think that students do not have any responsibilities. Hence, this leads to undesired behaviours.

Therefore, teachers should give responsibility to the students. In this sense, teacher should know the characteristics of students and give responsibility in this direction. However, teachers should be careful that the responsibility they give should not be perceived as a punishment. Those responsibilities should help students to control their own behaviours [17].

The most common undesired behaviours seen in the classroom are the unwelcomed behaviours such as the improper way of the usage of classroom tools, resistance to teachers, taking the things that belong to another person without permission, preventing others from participating the classroom and whispering to each other [18]. Besides talk of demolition, distracting the others, being unelaborate, talking with friends during the lecture, interesting with other unrelated things during the lectures, being rude and impolite to his/her friends and teachers, harming school articles, absence, cheating can be also regarded as the undesired classroom behaviours [19]. The most common mistakes done by teachers toward undesired behaviours are ignoring small mistakes, disregarding the provocative behaviours, avoiding eye contact, rebuking, complaining to family, referring to discipline commission and demoralizing [19].

Even theoretical pedagogical knowledge cannot be helpful for classroom management. This knowledge should be supported by the activities with teacher candidates. According to Köse Özay [20], even though teachers have a pedagogical background, they cannot deal with the undesired student behaviours in the real classroom conditions. "In these situations, teachers may prefer some evasive methods to solve crises" [9]. According to a study done by Çubukçu and Girmen [16], the area of planning and educational activities are found to be among the lowest level areas. Besides, if their relation with the classroom management and function is taken into the consideration, this may result in undesired classroom behaviours as well.

In the study of Güleç and Alkış [21] conducted to 87 teachers working in public schools, in case of undesired situations, it is revealed that $\% 3.4$ of them states "they do not want students doing irrelevant talk with the rest of the class", $\% 4$ of them state that "they criticize students", $\% 4,6$ of them prefer "no corporal punishment", $\% 2.3$ of them state that "I do not give them a break". In another study done by Bayraktar and Çınar [8], conducted to 110 Science and Technology teachers, it is revealed that the teachers always do the demotivational behaviours such as ridiculating, insulting. The study shows that $\% 20$ of the teachers always call students with negative titles, $\% 12$ of teachers do this often. In the study of Sadik [22] conducted his research in the same school, the strategy of teachers dealing with undesired behaviours are classified into 12 categories. These are, verbal warning, warning by using body language, giving advice and explanation, intimidating, lowering grades, isolation, deprivation of something they like, the usage of force, communication with family, forcing them to do something, humiliation, mocking and giving writing tasks as a punishment. Whereas teachers consider those as preventive and curative behaviours, students qualify those as punitive behaviour, they think they are scary and unfair [22]. In the literature, the undesired behaviours of students in classroom conditions and the strategies that teachers used toward those kinds of behaviours are similar. This study differs from previous studies in terms of revealing teachers' mistakes and evasive attitudes hereby letting them to evaluate and make self-criticization of their behaviours.

The behaviours of students in classrooms are highly correlated with classroom atmosphere, physical conditions of the classes, the personal abilities of teachers and their self-perception of leadership. Thus, the related teacher behaviors are seen important by the teachers and become the main theme of this study. So, the aim of this study is to determine the most common mistakes done by teachers in the view of teacher candidates.

There are few studies revealing teachers' most common mistakes whether they are intentional or not. Therefore, this study provides teacher candidates to make self-evaluation and teachers to realize their attitudes in the classroom. The Ministry of National Education works on the criteria and standards of a qualified teacher [23]. This study highlights the importance of this approach by identifying teachers' behaviors in the classroom.

\section{Materials and Methods}

\subsection{Research Method}

This study is designed as a qualitative-descriptive study. In descriptive studies, current situation is analyzed without any manipulation and the main aim is to reflect the current situation as it is. Qualitative data collection tool, which is designed by researchers, is used to identify teacher trainees' opinions about their former teachers' mistakes. In qualitative studies, participants' experiences can be identified systematically [28].

\subsection{Population and Sample}

The population of this study consists of 3rd grade students in Education Faculty in Mustafa Kemal University during 2012-2013 spring term. The target population is 3rd grade students from the departments of English Language Teaching, Turkish Language Teaching and Art Teaching. From this target population, participants are selected through convenience sampling method. As a result, 114 students from English Language Teaching department, 123 students 
from Turkish Language Teaching department and 39 students from Art Teaching department are selected for this study.

\subsection{Data Collection}

The questionnaire is used as a measurement tool. The exam period of the year is thought to be practical to collect data at once from students. Researchers asked students to answer the question by considering all teachers in their academic life and their most common mistakes according to their opinions. There are not any limitations about the number of their answers. Students usually answer according to experiences with their lecturers in the university.

\subsection{Data Analysis}

Content analysis method is used to analyze the data. The answers from students to one open ended question are organized as a list of statements by researchers. 742 teachers' common mistakes are stated. The second step of analysis is clustering similar statements into groups. As a result of the second step, 242 statements are listed. In the following part, some words or sentences are chosen as codes in accordance with the repetition, likelihood and frequency. Two different researchers coded the same data independently for reliability issues. Then, these codes are discussed and final decisions are made through consensus between two researchers. Intercoder Agreement Percentage which is suggested by Miles and Huberman (1994) is used to find out reliability of the research, and it is calculated as .92 .110 concepts emerge after coding is done. These concepts are presented in the Table 1. 6 different themes are defined according to the relations between concepts. These themes are classroom management and discipline, teaching, communication, personal characteristics, professional ethics and evaluation of the course. Other statements of students are organized in the 'others' category which is given in Table 8 . Frequencies of Teacher Trainees statements are given to provide face validity. The purpose of stating frequencies is not for generalization, but for objectivity [29].

\section{Findings}

In this part, the findings of the study are presented in the tables with frequencies according to the themes emerged.

Table 1. Emerging Concepts about Teachers' Most Common Mistakes

\begin{tabular}{|c|c|c|c|c|}
\hline No & Concepts & Concepts & Concepts & Concepts \\
\hline 1 & No transfer & Mistake & Lack of material & Wrong intonation \\
\hline 2 & Mocking & Intolerance & Aloofness & Boring lesson \\
\hline 3 & Enigmatic & Ideological attitudes & Inappropriate behaviours & Making students passive \\
\hline 4 & Lack of comprehension & Lack of Communication & Authority & No answer for questions \\
\hline 5 & Sullen face & Giving unrelated examples & Lecturing while sitting & Threatening by questions \\
\hline 6 & Scolding & Apathy & Not applicable homework & Irresponsibility \\
\hline 7 & Pressure & Unwillingness & Differences among students & Generalizations of problems \\
\hline 8 & Attention to successful students only & Lack of functionality & $\begin{array}{c}\text { The level of students' } \\
\text { achievements }\end{array}$ & Lack of social activities \\
\hline 9 & Absence of teacher & Disclaiming & Disabling students & Abstract lessons \\
\hline 10 & Punishment & No anxiety & Blaming students & No voice for students \\
\hline 11 & Drinking tea, coffee during the class & Lack of resources & Teacher centered & Playing games \\
\hline 12 & Talk too much & Be on his/her mettle & No planning & Violence \\
\hline 13 & Mocking & Comparing students & Disregard & No discussion \\
\hline 14 & No valuing students & Getting angry & Unimportant lesson & Threatening \\
\hline 15 & No inspection & Personal weakness & Prejudice & Routinized lesson \\
\hline 16 & Problems out of lesson & Personal affairs & No usage of examples & No revising \\
\hline 17 & Being late & Personal issues & Ineffective methods & Scolding \\
\hline 18 & Quick start & Personal problems & Passiveness & Inconsistency \\
\hline 19 & Leaving the class & Bookish & No reinforcement & No performing \\
\hline 20 & Lack of attention & $\begin{array}{l}\text { Lecturing by reading from } \\
\text { book }\end{array}$ & Psychological problems & Careless \\
\hline 21 & No listening & No control & Insulting & Lying \\
\hline 22 & Not open to criticism & Not finishing the syllabus & Only Lecturing during the lesson & Wrong information \\
\hline 23 & No empathy & Frightening & Lecturing & Wrong Turkish \\
\hline 24 & Impose & Bad behaviour & Only writing to blackboard & Wrong method \\
\hline 25 & Inequality & Bad role model & Disrespect & Inadequacy \\
\hline 26 & Ineffectiveness & Humiliating & Releasing & High expectation \\
\hline 27 & Memorization & $\begin{array}{l}\text { Call to the chalkboard from the } \\
\text { list }\end{array}$ & Ill-humor & Wrong timing \\
\hline 28 & Distrust & Pecuniary advantage & & \\
\hline
\end{tabular}


Concepts emerging from participants' statements are presented in Table 1. There are 110 concepts in total which are mostly remarkable such as mocking, lack of comprehension, pressure, punishment, ignoring students, inequality, distrust, apathy, unwillingness, getting angry, frightening, violence, threat, inconsistency and inadequacy. This picture shows how students see their teachers.

Teachers' most common mistakes are given in the category of "classroom management and discipline" according to participants' statements. The most common mistake in this category is about the authority; not establishing authority and establishing authority by ill-humor. Besides, students think that teachers establish the authority by violence or pressure. Making students passive, scolding and frightening students as well as threatening them is among the other common mistakes of teachers in this study.
Table 2. Teachers' Most Common Mistakes concerning "Classroom Management and Discipline"

\begin{tabular}{|c|c|c|}
\hline No & $\begin{array}{c}\text { Mistakes concerning "Classroom management and } \\
\text { Discipline" }\end{array}$ & $\mathrm{f}$ \\
\hline 1 & Not establishing authority & 16 \\
\hline 2 & Establishing authority by ill-humour & 14 \\
\hline 3 & Seeing himself/herself as the only authority & 5 \\
\hline 4 & Too authoritarian & 5 \\
\hline 5 & Oppressive practice & 4 \\
\hline 6 & Discipline by violence & 2 \\
\hline 7 & Making students passive & 1 \\
\hline 8 & Scolding students & 1 \\
\hline 9 & Frightening students & 1 \\
\hline 10 & Pressure & 1 \\
\hline 11 & Establishing authority by threat & 1 \\
\hline 12 & Giving punishment & 1 \\
\hline 13 & No controlling the class and time & 1 \\
\hline 14 & Violence as punishment & 1 \\
\hline 15 & Not controlling the lesson & 1 \\
\hline 16 & Being passive in the lesson & 1 \\
\hline
\end{tabular}

Table 3. Teachers' Most Common Mistakes Concerning "Teaching"

\begin{tabular}{|c|c|c|}
\hline No & Mistakes Concerning "Teaching” & f \\
\hline 1 & Using only lecturing methods unsuccessfully & 76 \\
\hline 2 & Incompetency in content knowledge & 36 \\
\hline 3 & Teacher centred lessons & 25 \\
\hline 4 & Having personal conversations during the lesson & 24 \\
\hline 5 & Incompetency in pedagogical knowledge & 18 \\
\hline 6 & Not considering individual differences & 18 \\
\hline 7 & Not motivating students in the lesson & 18 \\
\hline 8 & Ineffective usage of homework & 17 \\
\hline 9 & Not using adequate material and technology & 17 \\
\hline 10 & Conducting lesson with successful students & 15 \\
\hline 11 & Not using updated and new instructional methods & 13 \\
\hline 12 & Insufficient practice & 13 \\
\hline 13 & Lessons depending on memorization & 13 \\
\hline 14 & Rebuffing students who give wrong answer & 12 \\
\hline 15 & Making students teach the lesson & 11 \\
\hline 16 & Wrong intonation & 9 \\
\hline 17 & Lecturing from the book & 9 \\
\hline 18 & Not revising the course according to students' characteristics and for needs & 9 \\
\hline 19 & Sitting while lecturing & 8 \\
\hline 20 & No planning before lesson & 5 \\
\hline 21 & Quick start to lesson without any warm up & 5 \\
\hline 22 & Not relating the course with real life & 5 \\
\hline 23 & Picking an inappropriate method for the course & 4 \\
\hline 24 & Not making the abstract concepts concrete & 4 \\
\hline 25 & Spending the lesson hour with only lecturing & 4 \\
\hline 26 & Not repeating and practicing & 3 \\
\hline 27 & Pushing students to be active & 3 \\
\hline 28 & Writing to the board entire lesson & 3 \\
\hline 29 & Picking the easiest method to conduct the lesson & 3 \\
\hline 30 & Not including social activities & 3 \\
\hline 31 & Leaving the class and drinking tea-coffee, behaving arbitrarily & 3 \\
\hline 32 & Leaving students free to do irrelevant things & 4 \\
\hline 33 & Asking questions suddenly & 2 \\
\hline 34 & Not finishing the lesson on time & 2 \\
\hline 35 & Not using adequate sources & 2 \\
\hline 36 & Not answering students' questions & 2 \\
\hline 37 & Giving inappropriate and unrelated examples & 2 \\
\hline 38 & Not giving equal speaking time for all students & 2 \\
\hline
\end{tabular}




\begin{tabular}{|c|c|c|}
\hline 39 & Not following the instructions in selected method & 2 \\
\hline 40 & Not including activities and enough examples & 2 \\
\hline 41 & Conducting boring lessons & 2 \\
\hline 42 & Using ideological view in class & 2 \\
\hline 43 & Making students deal with her/his personal works & 2 \\
\hline 44 & Extending the lesson hour & 2 \\
\hline 45 & Playing games in the class & 1 \\
\hline 46 & Ignoring students' psychological well-beings & 1 \\
\hline 47 & Making students responsible with the untaught parts of the course & 1 \\
\hline 48 & Blaming students in case of the lesson is not understood & 1 \\
\hline 49 & Behaving bad to students & 1 \\
\hline 50 & Not motivating students & 1 \\
\hline 51 & Teaching intensively in the end of the school year due to the lack of time & 1 \\
\hline 52 & Calling student to the board from students' list & 1 \\
\hline 53 & Teaching even though students are not motivated & 1 \\
\hline 54 & Giving wrong information & 1 \\
\hline 55 & Emphasizing the unnecessary parts of the lesson & 1 \\
\hline 56 & Teaching not according to students but to himself/herself & 1 \\
\hline 57 & Not paying enough attention to the must do's & 1 \\
\hline 58 & Not creating the discussion platform & 1 \\
\hline 59 & Paying too much attention to some unnecessary detailed issues and so missing the important issues & 1 \\
\hline 60 & Talking too much & 1 \\
\hline 61 & Giving too much responsibility and leaving no time for students & 1 \\
\hline
\end{tabular}

Table 3 presents the most common mistakes of teachers concerning teaching. Students mostly think that the method of instruction is not appropriate and direct instruction is the most chosen one, which seems dissatisfying for students. Besides, teachers incompetency in content and pedagogic knowledge, teacher-centered courses, ignoring individual differences, conducting lessons with successful students, not making practices, not using materials, not activating students in the class, to make students to teach, being slave of the course book and teaching while sitting are the other statements of participants about mistakes concerning teaching.

Table 4. Teachers' Most Common Mistakes Concerning "Communication"

\begin{tabular}{|c|c|c|}
\hline No & Mistakes concerning communication & $\mathrm{f}$ \\
\hline 1 & Not having smile on their face & 14 \\
\hline 2 & Not communicating effectively with students & 10 \\
\hline 3 & Mocking students & 9 \\
\hline 4 & Not wishing to answer students' questions & 6 \\
\hline 5 & Keeping students at a distance & 4 \\
\hline 6 & Not listening students & 3 \\
\hline 7 & Not speaking Turkish properly & 2 \\
\hline 8 & Not being open to criticism & 2 \\
\hline 9 & Not having talk with students & 2 \\
\hline 10 & Not speaking fluently & 2 \\
\hline 11 & Not giving voice to students & 1 \\
\hline 12 & Not adjusting the volume of their voice & 1 \\
\hline 13 & Insulting students & 1 \\
\hline 14 & Not using mimics and gestures properly & 1 \\
\hline 15 & Lying & 1 \\
\hline 16 & Generalizing one problem related with one student to & 1 \\
\hline
\end{tabular}

Not having smile on their face, not having an effective communication and making fun of students in the classroom are among the most common mistakes of teachers concerning communication. In this category, not wishing students to ask questions, keeping students at a distance, not listening students, not speaking Turkish properly and not being open to criticism are the other statements, which are seen mistakes in communication.

Table 5. Teachers' Mistakes that are related to their Personal Traits

\begin{tabular}{|c|c|c|}
\hline No & Mistakes that are related to Teachers' Personal Traits & $\mathrm{f}$ \\
\hline 1 & Being nervous & 13 \\
\hline 2 & Not being calm and understanding & 5 \\
\hline 3 & Having weaknesses in their personality & 2 \\
\hline 4 & Showing their weaknesses to students & 2 \\
\hline 5 & Trying demonstrate himself with the grades s/he gives & 2 \\
\hline 6 & Being impatient & 2 \\
\hline 7 & Saying: "I know everything" & 2 \\
\hline 8 & Not doing what s/he said & 1 \\
\hline 9 & Being unaware of social and cultural events & 1 \\
\hline 10 & Not having responsibility about teaching profession & 1 \\
\hline 11 & Pretending to be as a nervous teacher & 1 \\
\hline 12 & Reflecting their psychological problems to students & 1 \\
\hline 13 & Not being empathetic & 1 \\
\hline 14 & Acting inappropriately as a teacher & 1 \\
\hline 15 & Not being tolerant & 1 \\
\hline
\end{tabular}

Teachers' positive personal traits always contributed to teachers' communication with students and achievement. However, some negative personal traits that everybody can have affect teachers' performance in classroom negatively. Students' opinions about teacher mistakes related to 
teachers' personal traits are given on the table above. As understood from the table, according to students, teachers' being nervous, not being calm and understanding, showing their weaknesses to students, showing their authority with the grades they give and being impatient are considered as mistakes among the mistakes that are originated from their personal traits.

Table 6. Teachers' Mistakes that are related with their Professional Ethics

\begin{tabular}{|c|c|c|}
\hline No & $\begin{array}{c}\text { Teachers' mistakes that are related with Professional } \\
\text { Ethics }\end{array}$ & f \\
\hline 1 & Not behaving equally with students & 58 \\
\hline 2 & Threatening students with grades & 7 \\
\hline 3 & Undervaluing and humiliating students & 6 \\
\hline 4 & Doing their job only for material goods & 3 \\
\hline 5 & $\begin{array}{c}\text { Not being interested with students' out of class } \\
\text { problems }\end{array}$ & 2 \\
\hline 6 & Being prejudice & 2 \\
\hline 7 & Reflecting his/her personal thoughts to students & 2 \\
\hline 8 & Disliking his/her job & 2 \\
\hline 9 & Not behaving according to students' characteristics & 2 \\
\hline 10 & Not trusting students & 2 \\
\hline 11 & Blaming the whole class for one students' mistake & 2 \\
\hline 12 & Imposing his ideological thoughts to students & 2 \\
\hline 13 & Evaluating students according to their characteristics & 1 \\
\hline 14 & Sharing exam questions with students before the exam & 1 \\
\hline 15 & Being late to the class & 1 \\
\hline 16 & Pressuring students with questions & 1 \\
\hline 17 & $\begin{array}{c}\text { Having high expectations from students despite not } \\
\text { teaching anything }\end{array}$ & 1 \\
\hline 18 & Making students spend too much without thinking \\
about their financial situation & 1 \\
\hline 19 & $\begin{array}{r}\text { Getting angry with students who say they do not } \\
\text { understand }\end{array}$ & 1 \\
\hline 20 & Not respecting to students & 1 \\
\hline
\end{tabular}

According to student thoughts, one of the categories of teachers' mistakes is related with professional ethics. In this type of mistakes, students mostly state that teachers lose their fairness. Besides this, it is thought that teachers also do mistakes such as threatening students with grades, humiliating students, doing job only for material goods, being prejudice, reflecting their personal thoughts to students and disliking their job.

Table 7. Teachers' Mistakes that are related to "Evaluation of the Students"

\begin{tabular}{|c|c|c|}
\hline No & $\begin{array}{c}\text { Teachers' Mistakes that are related to Evaluation of } \\
\text { Students }\end{array}$ & $\mathrm{f}$ \\
\hline 1 & Not considering a student as an individual & 5 \\
\hline 2 & Ignoring the class performance & 1 \\
\hline 3 & Not correcting students' mistakes & 1 \\
\hline 4 & Not giving research questions & 1 \\
\hline 5 & Not checking the responsibilities of students & 1 \\
\hline 6 & Punishing by grades & 1 \\
\hline 7 & Hurting students by their low academic achievement & 1 \\
\hline 8 & Not evaluating the course & 1 \\
\hline 9 & Evaluating inaccurately & 1 \\
\hline
\end{tabular}

In table 7, Students' thoughts about teachers' mistakes that are related to student evaluation are stated. According to the table, one mistake that is mostly made is not considering a student as an individual. Besides, teachers also make mistakes such as ignoring in class performance, not correcting students' mistakes, punishing by grade.

Table 8. Other Mistakes that Teachers Make

\begin{tabular}{|c|c|c|}
\hline No & Other Mistakes & $\mathrm{f}$ \\
\hline 1 & Not dressing in an appropriate manner & 5 \\
\hline 2 & Being unaware about student psychology & 5 \\
\hline 3 & Ignoring students' interests, desires, and expectations & 3 \\
\hline 4 & Not dealing with students individually & 2 \\
\hline 5 & Being bad role model for students & 1 \\
\hline 6 & Believing s/he does her job perfectly & 1 \\
\hline 7 & Being reluctant and uninterested towards the course & 1 \\
\hline 8 & Seeing students as children & 1 \\
\hline 9 & Not admitting his/her mistakes & 1 \\
\hline 10 & Not using proper rewards and reinforcements & 1 \\
\hline 11 & Giving too much responsibility to students & 1 \\
\hline 12 & It is ok for him/her that only a few students understand & 1 \\
\hline 13 & the subject & 1 \\
\hline 14 & Not being up to date current issues & 1 \\
\hline 15 & Not caring about teaching & 1 \\
\hline
\end{tabular}

Mistakes that are made by teachers and cannot be categorized in one theme are listed above. According to table, teachers mostly make mistakes such as not caring their clothes in class, being unaware about psychology of students, ignoring students' interests, desires, and expectations, not dealing with students individually and being bad model for students.

\section{Discussion}

Findings of the research show that themes of teachers' mistakes are classroom management, discipline, teaching process, communication, personal traits, professional ethics and evaluation of students.

Although teacher mistakes are classified in different themes, there is a horizontal relationship between these themes. For example, there can be direct relationship between teachers" "being nervous" which is one of their personal traits and "being surly", "not communicating", " not being open to criticism", and "hold off with students" which are communication mistakes.

Some serious problems in teaching emerge from teachers' usually using traditional teacher-centered teaching methods, behaving authoritatively, and being inadequate for adapting themselves up to date. For example, some mistakes in teaching such as using teacher-centered teaching, using inadequate teaching methods, teaching for memorization, teaching while sitting in the chair, using book all the time, 
making lessons dull, not being able to make subjects concrete for students are related directly to teachers' professional inability.

After research findings are evaluated as a whole, it is seen that they are directly related to "Teacher Competencies" of Teacher Education and Development General Management of Ministry of Education [24]. Teacher competencies are categorized under six subtitles which are Personal and Professional Values-Professional Development, Knowing Students, teaching and learning processes, following/evaluating learning and development, school, family and society relations, Program and Content Knowledge. Our findings in this research are consistent with these categories and performance indicators. In behaviour management dimension of the third category (Teaching learning processes), it is expected from teachers to take students' successful areas into account to prepare lessons accordingly, such as by caring individual differences, determining classroom rules with the students, managing feelings and thoughts and having self-control. However, our findings show that teachers cannot establish the authority. Hence, they behave firmly while trying to control the class, scare, threaten, assimilate students, and the use punishment.

The central idea of all contemporary approaches such as constructivism, project based learning, multiple intelligence theory, thinking skills, collaborative learning, teaching and learning styles, quantum learning, emotional intelligence, brain based learning, allosteric learning, suggestopedia, accelerated learning, NLP (neuro linguistic programming), left and right brain theory, triple brain theory, and holistic learning that emerged in last 20 years is that they give importance to individual(learner) and they make learner active [25]. In teaching competencies, it is stated that teacher should know students' physical, social, cognitive, linguistic, and cultural development level, students' interest and needs, and their strengths and weaknesses [24]. In research findings, it is found that teachers scold and behave badly to students who answer incorrectly, giving homework as punishment which is opposed to its educational purpose, make students passive in the class, they do not teach using active teaching methods.

In addition, it is found that teachers do not behave students equally in the class, threaten students with grades, undervalue students, they are prejudiced to students, they insult students, assimilate students, and they do not respect to students. Actually, teachers have desired and ideal attitudes while they are graduated, [26], later authentic learning environments and institutional culture may lead teachers to do these mistakes. In this point, it can be said that there are some serious problems that are related to honor and ethics in learning environments.

In assessment and evaluation of learning outcomes, it is expected from teachers that they should use the correct assessment technique, they should assess students by using correct, reliable and valid scale, and they should interpret the results and give feedback, and share these with the stakeholders. [24]. However, according to results of the research, teachers are lack of feedback and correction, they do not give importance to individual characteristics and they use grades as punishment.

In addition, not caring their clothes in class and ignoring students' desires and expectations are some of mistakes that are made by teachers in the classroom.

\section{Conclusions and Suggestions}

\subsection{Conclusion}

Findings according to the aim of the research and content analysis are gathered under six themes. These themes are: Classroom Management and Discipline, Teaching, Communication, Personal Traits, Professional Ethics, Measurement and Evaluation, and other mistakes. While writing the conclusion, most popular three mistakes in findings according to these themes are considered.

- It is noticed that under the theme of classroom management and discipline teachers mostly make mistakes such as not establishing teacher authority or being rigid to establish authority, being too much authoritative and disciplined, seeing himself/herself as an authority and assimilating by being oppressive. Besides, teachers also try to establish the authority by scolding, scaring, assimilating, violence and punishment.

- In relation with teaching process, teachers are lack of using proper methods and techniques, they adopt traditional teacher-centered education, and teachers do not improve themselves, and accordingly these leads to many problems. Not making students active in class, not utilizing materials, technology and activities, not being prepared for the class are among the basic problems in teaching process.

- The fundamental problems regarding communication can be given as not being indulgent and good humored, negative attitudes, making fun of students in the classroom and not making students love the course. Also, teachers do some serious communication mistakes such as not being open to criticism, being surly, not listening to students, silencing student and generalizing.

- In terms of teachers personal traits, mistakes are stated as being nervous, not being calm and understanding, threatening with grades, claiming he/she is the best, reflecting his/her psychological problems in class, not being emphatic, not being indulgent, and acting inappropriately as a teacher.

- Not behaving equally to students is the most common teacher mistake in the category of professional ethics. Besides, threatening, undervaluing, humiliation, being prejudiced, insulting, not trusting to students, reflecting ideological behaviors, assimilation, getting angry and not respecting are mistakes that teachers make. 
- In terms of evaluation of students, some unfavorable behaviors such as inadequate feedback and correction, not considering students as an individual, using grades as punishment are stated.

\subsection{Suggestions}

- After Teacher mistakes that are found and Teacher Competencies of Ministry of Education are considered, first suggestion is that teachers need constant following during the time of selection of the profession and doing the profession. Unfortunately, it is seen that national exams for teacher selection (LYS) and nomination of teachers (KPSS) are not adequate. For that reason, teacher competencies that are not evaluated during these processes but which are demanded from teachers should be evaluated, and they should be decisive while nominating teachers. Affective domain should also be considered while selecting teachers.

- After nomination of teachers, teachers should be followed constantly in different ways. With this purpose, there should be a system in which students, colleagues, parents, inspectors and managers can evaluate teachers, and the evaluations should be shared with the teachers. This evaluation is done in some universities in Turkey.

- The quality of teacher education should be enhanced through curriculum evaluation. In education faculties, professional ethics courses should be taught and communication skills should be emphasized.

\section{REFERENCES}

[1] Gelen, İ. Eğitimde Okul ve Sınıf (244-276), Eğitim Bilimine Girişs (Edt. Mehmet Taşpınar), Ankara, Elhan Kitap (ISBN:978-605-63263-4-9), 2012.

[2] Dilekmen, M. Etkili Eğitim İçin Etkili Öğretmenlik, Atatürk Üniversitesi Sosyal Bilimler Enstitüsü Dergisi, 12 (2): 213-221, 2008.

[3] Bursalığlu, Z. Eğitim Örgütüne Sistem Yaklaşımı, Ankara Üniversitesi Eğitim Bilimleri Fakültesi Dergisi, 4(1): 65-73, 1971.

[4] Aydın, S. \& Boz, Y. Fen öğretmen eğitiminde pedagojik alan bilgisi araştırmalarının derlenmesi: Türkiye örneği. Kuram ve Uygulamada Ĕgitim Bilimleri, 12, 479-505. 2012.

[5] Emmer, E.T, \& Hickman, J. Teacher efficacy in classroom management and discipline. Educational and Psychological Measuremen, 51, 755-765, 1991.

[6] Stephens, P. \& Crawley, T. Becoming on Effective Teacher, Cheltenham Stanley Thornes Publishers Ltd.: 9, 1994.

[7] Yeşilyurt, E. \& Çankaya, İ. Sınıf Yönetimi Açısından Öğretmen Niteliklerinin Belirlenmesi, Elektronik Sosyal Bilimler Dergisi, 7 (23): 274-295, 2008.
[8] Bayraktar, Ş. \& Çınar, D. Öğretmen Adaylarının Gözü ile Fen Ve Teknoloji Öğretmenlerinin Etkili Öğretmen Davranışlarını Gerçekleştirme Düzeyleri, Ahi Evran Üniversitesi Eğitim Fakültesi Dergisi, 11(3), 131-152, 2010.

[9] Özer, B. Avoidance Strategies Used by Educators İn Difficult Classroom Situations. International Journal of Academic Research Part B; 5(2), 34-43. DOI: 10.7813/2075-4124.201 3/5-2/B.5, (2013).

[10] Atıc1, M. Öğretmen Yetkinliği, Kuram ve Uygulamada Ĕ̈itim Yönetimi, Online available from http://www.pegem.n et/ dos yalar/dokuman/1146-201107141 4435 4-atici.pdf.

[11] Baştürk, S. Mutlak Değer Kavramı Örneğinde Öğretmen Adaylarının Öğrenci Hatalarına Yaklaşımları, Necatibey Faculty of Education Electronic Journal of Science and Mathematics Education, 3(1), 174-194, 2009.

[12] Şahin, İ., \& Altunay, U. İköğretim Okulu Öğretmenlerinin Sınıf Yönetimi Davranışları. Ilkögrretim Online, 10 (3), 905-918, 2011.

[13] Can, N. Öğretmen Liderliği Becerileri ve Bu Becerilerin Gerçekleştirilme Düzeyi. Sosyal Bilimler Enstitüsü Dergisi, 1, 263-288, 2007.

[14] Örücü D., Primary School Teachers? Metaphorical Perspectives towards Classroom and Classroom Management: A Comparative Case Study. Ilköğretim Online, 11(2), 2012

[15] Akar, H., Tantekin Erden, F., Tor, D., \& Şahin, İ. T. Öğretmenlerin Sınıf Yönetimi Yaklaşımları ve Deneyimlerin in İncelenmesi. İlkögrretim Online, 9(2), 792-806, 2010.

[16] Çubukçu, Z. \& Girmen, P. Öğretmenlerin Sınıf Yönetimi Becerilerine İlişskin Görüşleri, (BILIG) Türk Dünyası Sosyal Bilimler Dergisi, 44: 123-142, 2008.

[17] Başar, H. Sınıf Yönetimi. M.E.B. Yayınları. İstanbul, 1999.

[18] Erdoğan, İ. Sinıf Yönetimi. İstanbul: Sistem Yayıncılık, 2004.

[19] Baloğlu, N. Etkili Sinıf Yönetimi Ankara: Baran Ofset, 2001.

[20] Köse Özay, E. Sınıf Yönetimine Yönelik Öğretmen Adaylarının Görüşleri, Ç.Ü. Eğitim Fakültesi Dergisi: 39, 20-27, 2010.

[21] Güleç, S. \& Alkış, S. Öğretmenlerin Sınıf Ortamında Kullandıkları Davranış Değiştirme Stratejileri, Uluda $\breve{g}$ Üniversitesi Eğitim Fakültesi Dergisi,17(2), 247 - 266, 2004.

[22] Sadık, F. İstenmeyen Davranışlarla Baş Etme Stratejilerinin Öğretmen ve Öğrenci Görüşlerine Göre Değerlendirilmesi. Illköğretim Online, 7(2), 232-251, 2008.

[23] MEB, Öğretmenlik Mesleği Genel Yeterlikleri. Devlet Kitapları Müdürlüğü, Ankara, 2008.

[24] MEB, Online available from http://otmg.meb.gov.tr/belgeler/ ogretm en yeterlikleri_kitabi/\%C3\%96\%C4\%9 Fretmen_Yet

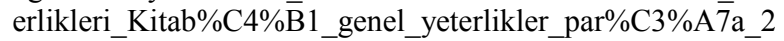
.pdf,

[25] Gelen, İ. Evaluating secondary school students' levels of five mind areas in terms of some variables. Educational Research and Reviews, 10 (2), 119-129, 2015. 
[26] Miles, M. B., \& Huberman, A. M. (1994). An expanded sourcebook qualitative data analysis. 2. Bask1. California: Sage Publications, Inc.

[27] Gelen, İ. \& Özer, B., Having general adequacy of teaching profession evaluation of the views of teacher candidates", Mustafa Kemal University Journal of Social Sciences
Institute, 5(9), 39-55 2008.

[28] Ekiz, D. (2003). Eğitimde Araştırma Yöntem ve Metotlarına Giriş, Ankara: Anı Yayıncılık.

[29] Maxwell, J. A. (1992). Understanding and validity in qualitative research. Harvard Educational Review, 62, 979-1000. 